\title{
Instrumentation and calibration of the Calvet calorimeter
}

\author{
Enthalpy of solution of $\mathrm{PrBr}_{3}$ at standard conditions
}

\author{
Beata Salamon · Jan Kapała • Marcelle Gaune-Escard
}

$3^{\text {rd }}$ Joint Czech-Hungarian-Polish-Slovak Thermoanalytical Conference Special Chapter

(c) The Author(s) 2011. This article is published with open access at Springerlink.com

\begin{abstract}
The original Calvet calorimeter, made from aluminum block, were instrumented. The cells for the solution calorimetry measurement have been projected and constructed. The calibration of calorimeter was performed by measurement of the dependence of reference material on temperature and the influence of mechanical events on thermograms. The enthalpies of solution in water and $0.01 \mathrm{M} \mathrm{HCl}$ were investigated for chlorides and bromides

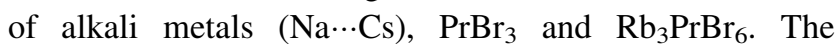
enthalpies of solution of alkali halides have been compared to the reference data obtained for infinite solution. The decomposition of $\mathrm{Rb}_{3} \mathrm{PrBr}_{6}$ at temperatures lower than $399 \mathrm{~K}$ has been stated. The enthalpy of solution $\mathrm{PrBr}_{3}$ at $298.15 \mathrm{~K}$ has been determined.
\end{abstract}

Keywords Solution calorimetry · Differential calorimeter · Praseodymium bromide - Alkali halides . $\mathrm{PrBr}_{3} \cdot \mathrm{Rb}_{3} \mathrm{PrBr}_{3}$

\section{Introduction and equipment description}

A microcalorimeter is composed mainly of the following parts: an external steel enclosure surrounding a calorimetric block. This cylindrical aluminum block $(500 \mathrm{~mm}$ diameter and $250 \mathrm{~mm}$ height) [1] contains two cavities

B. Salamon · J. Kapała $(\bowtie)$

Faculty of Chemistry, Wrocław University of Technology,

Wyb. St. Wyspiańskiego 27, 50-370 Wrocław, Poland

e-mail: jan.kapala@pwr.wroc.pl

M. Gaune-Escard

Ecole Polytechnique, Mecanique Energetique, Technopole de Chateau-Gombert, 5 Rue Enrico Fermi, 13453 Marseille

Cedex 13, France for one thermopile each and is surrounded by kanthal resistance and kaowool acting as a thermal insulation. Each thermopile is located in a cylindrical bottom-closed tube, a so-called "calorimeter cell" of thin-walled alumina. The thermopiles constitute the "hot" (internal) and "cold" (external) junctions, respectively of this sensing device. Each cell is $34 \mathrm{~mm}$ diameter and $120 \mathrm{~mm}$ high and the maximum thermal flux is integrated by the 750 thermocouples. Experimental calorimetric cells are equipped by the special mechanism for crushing glass ampoule with the sample. A small furnace for heating the reference material is placed over the cell. In order to obtain good stability of the apparatus with respect to time and temperature, the two thermopiles are connected in opposition. This twin construction in measures eliminates most problems associated with any exterior thermal perturbation. The sapphire ( $\alpha$-alumina) were used as the reference material (Standard Reference Material 720, NIST). They were heated up to about $150{ }^{\circ} \mathrm{C}$ and then dropped into the cells keeping at standard temperature. Temperature of reference material was controlled by thermocouple of $\mathrm{K}$ type with cold-junction compensation and by FLUKE 45 multimeter. Thermocouple was situated in stainless steel pipe (of $1 \mathrm{~mm}$ diameter). Temperature of main block of calorimeter has been stabilized by EUROTHERM 2404. Electromotive force of thermopile was measured by FLUKE 8808A digital multimeter and recorded. Logging interval time was one second.

\section{Experimental}

Chemicals used in this study were $\mathrm{NaCl}$ (POCh spectrum pure), $\mathrm{NaBr}$ and $\mathrm{KCl}$ ( $\mathrm{POCh}$ pure for analysis), $\mathrm{RbCl}$ 
(Aldrich pure for analysis), $\mathrm{KBr}, \mathrm{RbBr}$ and $\mathrm{CsBr}$ (Merck suprapure), $\mathrm{CsCl}$ (Alfa Aesar pure for analysis), $\mathrm{PrBr}_{3}$ was prepared before [2]. The metallic gallium (Aldrich 99.99\% trace metals basis) was used as a reference material. The calibration of thermocouple were done for two temperature points: melting point of water and melting point of gallium. After correction the precision of temperature measurements has been better than $0.1 \mathrm{~K}$ at standard temperature. We assume that this is good enough for our purposes.

The glass ampoules with investigated salts (from about 0.1 to about $1 \mathrm{~g}$ ), placed in experimental calorimetric cells together with $50 \mathrm{~mL}$ of solvent, were introduced into calorimeter cavities. When thermal equilibrium of the calorimeter was obtained (about $12 \mathrm{~h}$ ), glass ampoule with salt was crushed and thermal effect resulting from dissolution of the salt was recorded. After the dissolution experiment, pieces of $\alpha$-alumina (500-1,500 mg), kept in heater at about $370 \mathrm{~K}$, were dropped into the solution and the corresponding enthalpy increment was measured. The reference data of dependence of enthalpy on temperature for $\alpha$-alumina were taken from [3]. The example of this curve for $\mathrm{CsCl}$ which contain one of calibration measured simultaneously is shown in Fig. 1.

\section{Results and discussions}

\section{Calibration of calorimeter}

All calibrations were interpreted taking into account the kind of cell, because of the small differences of constructions. For each cells the calorimeter constant has been calculated separately and the results and statistical analysis are presented in Table 1. Statistical test shows that difference between both values is insignificant. However, for the

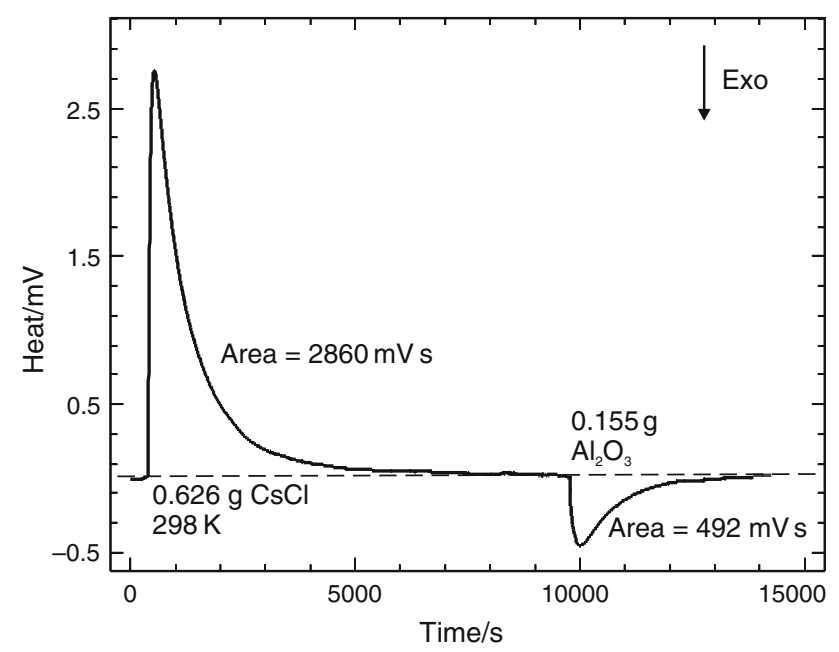

Fig. 1 The example of the measurement of $\mathrm{CsCl}$ with simultaneous calibration
Table 1 Calorimeter constants for both cells

\begin{tabular}{lcc}
\hline & Cell 1 & Cell 2 \\
\hline Number of experiments & 57 & 46 \\
Average $10^{5} / \mathrm{kJ}(\mathrm{mV} \mathrm{s})^{-1}$ & 2.495 & 2.605 \\
Standard deviation $10^{5} / \mathrm{kJ}\left(\mathrm{mV} \mathrm{s}^{-1}\right.$ & 0.120 & 0.114 \\
Standard skewness & 0.513 & -0.320 \\
Standard kurtosis & -0.716 & -0.615 \\
\hline
\end{tabular}

calculation of the enthalpy of solution the values of calorimeter constant were used separately. The quality of heating the reference material was controlled by analysis of the temperature dependence of calorimeter constant obtained for various temperatures of sapphires dropped into cell. The temperatures in this experiment were not selected sequentially. The comparison of this experiment with all calibrations (all were performed in the same cell) is shown in Fig. 2. There is no temperature dependence of calorimeter constant and no significant difference between this special experiment (black squares) and set of routine measurements (empty circles).

The thermal effect of crushing the empty ampoules were controlled. The influence of this effect was visible in experiments with small amount of sample and the small value of enthalpy of solution. The measured areas has been corrected by the $125 \mathrm{mV}$ s value as an exothermic effect.

During the preliminary measurements, the influence of various factors on the result has been observed. Important for the effect of the experiment is size and shape of ampoules prepared for crushing. If it is too large then the effect of rubbing ampoules against a wall of the cell is significant and can disturb the analyzed curve. Also, the crushing mechanism shows small thermal effect during

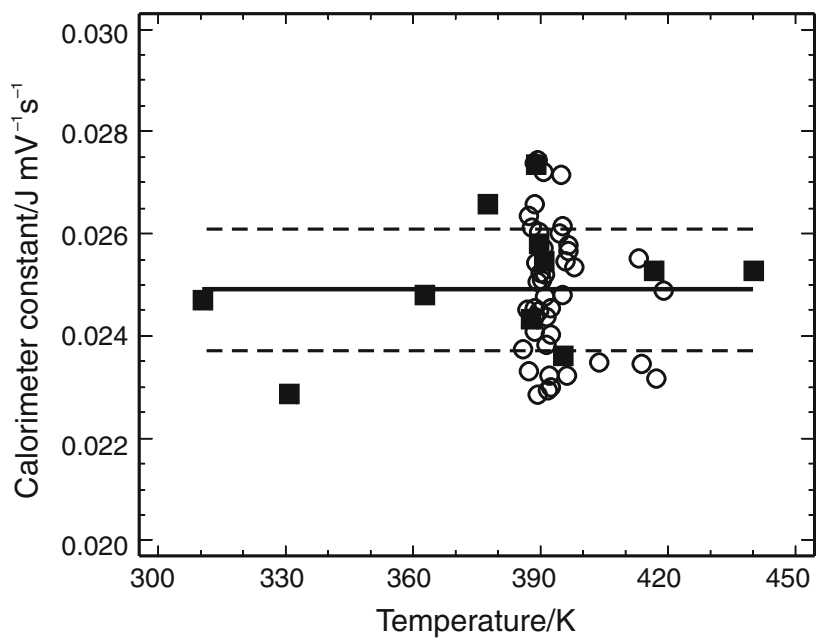

Fig. 2 The dependence of calorimeter constant on temperature at cell 1. Solid line shows the average value of this constant, dashed lines show the standard deviation of average value 
rotation of thread which may be negligible if its moving is small. The effect of rotation of the crushing screw is very small and depends on the rotation angle. The values obtained for one complete turn is about $130 \mathrm{mV} \mathrm{s}$ (exothermic effect). In the real experiment only part of this value was used.

The integrations of the dependences of thermal effect on time were done automatically by the especially written computer program. The results of investigation for alkali halides are shown in Table 2. The values of measured enthalpies of solution for alkali metals chlorides and bromides are satisfactorily consistent with reference data [4]. The abundance of measurement series was from 3 to 5 . The values of standard deviation for measured enthalpies of solution shows that measurement accuracy is from about $0.30 \mathrm{~kJ}$ to about $0.65 \mathrm{~kJ}$. The reference heat of solution for solid $\mathrm{KCl}$ in water at standard conditions is equal to $17.584 \pm 0.017 \mathrm{~kJ} \mathrm{~mol}^{-1}$ [5]. Assuming that low concentrations of $\mathrm{HCl}$ is negligible, the heat of solution obtained for solid $\mathrm{KCl}\left(17.59 \pm 0.33 \mathrm{~kJ} \mathrm{~mol}^{-1}\right)$ are in good agreement to the reference data. Absolute error for the calorimeter shows that measurement of the small values of enthalpy of solution for $\mathrm{NaCl}$ and $\mathrm{NaBr}$ may be relatively less accurate because of small values of their heat of solution. The influence of concentration on heat of solution for all of experiments are not observed. This is shown in Figs. 3 and 4.

The next limitation of precision is a maximum amount of sample which depends on a space for ampoule and movement range of crushing tool and relatively small volume of solvent in the cell. The maximum volume of solvent in cell is only about $70-80 \mathrm{~cm}^{3}$ but generally, we assume that the high sensitivity of thermopiles satisfactorily increases the sensitivity of calorimeter.

Table 2 The measured values of enthalpies of solution for alkali metal chlorides and bromides in $0.01 \mathrm{M} \mathrm{HCl}$ excluding reference data and one set of $\mathrm{NaCl}$ experiments

\begin{tabular}{lcc}
\hline Compound & $\begin{array}{l}\text { Enthalpy of solution/ } \\
\mathrm{kJ} \mathrm{mol}^{-1}\end{array}$ & $\begin{array}{l}\text { Reference data }^{\mathrm{b}} \\
\mathrm{kJ} \mathrm{mol}^{-1}[3]\end{array}$ \\
\hline $\mathrm{NaCl}^{\mathrm{a}}$ & $3.49 \pm 0,50(6)$ & $3.88^{\mathrm{a}}$ \\
$\mathrm{NaCl}$ & $4.09 \pm 0.49(5)$ & $3.88^{\mathrm{a}}$ \\
$\mathrm{KCl}$ & $17.59 \pm 0.33(3)$ & $17.22^{\mathrm{a}}$ \\
$\mathrm{RbCl}$ & $17.88 \pm 0.65(5)$ & $17.28^{\mathrm{a}}$ \\
$\mathrm{CsCl}$ & $18.43 \pm 0.32(4)$ & $17.78^{\mathrm{a}}$ \\
$\mathrm{NaBr}$ & $-4.00 \pm 0.51(4)$ & $-0.60^{\mathrm{a}}$ \\
$\mathrm{KBr}$ & $21.20 \pm 0.55(3)$ & $18.97^{\mathrm{a}}$ \\
$\mathrm{RbBr}$ & $21.95 \pm 0.53(3)$ & $21.88^{\mathrm{a}}$ \\
$\mathrm{CsBr}$ & $26.50 \pm 0.42(4)$ & $25.98^{\mathrm{a}}$ \\
\hline
\end{tabular}

The number of measurements are in the parentheses

a Solution in water

${ }^{\mathrm{b}}$ For infinite solution

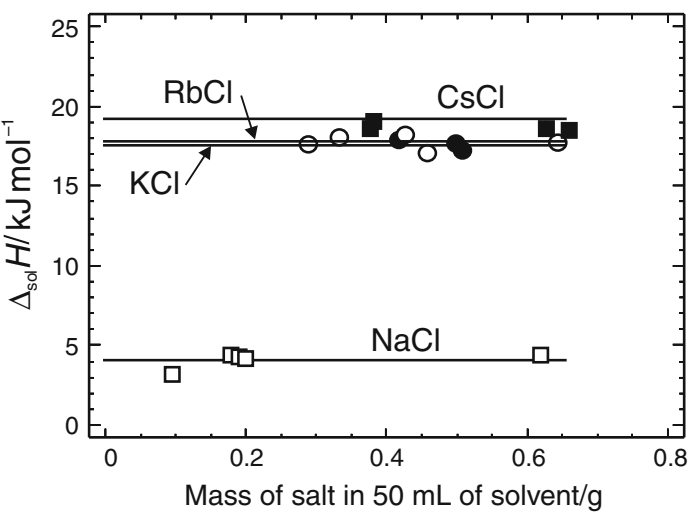

Fig. 3 The dependence of enthalpies of solution of alkali chlorides on concentration. The lines represent average values.

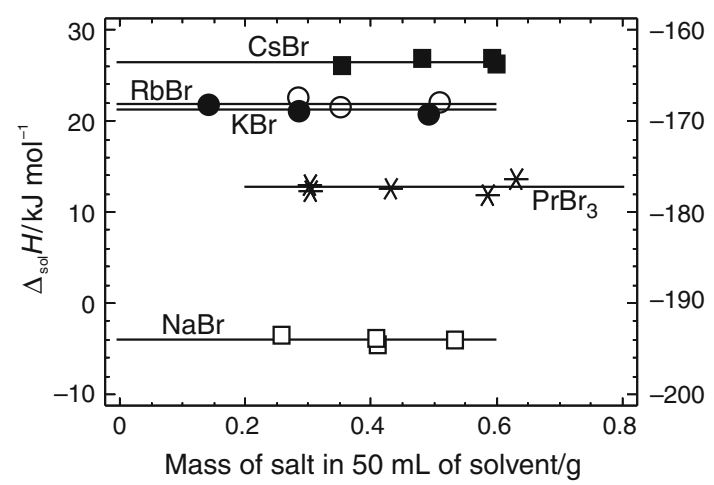

Fig. 4 The dependence of enthalpies of solution of alkali bromides and $\mathrm{PrBr}_{3}$ on concentration. Left scale-alkali bromides, right scale-praseodymium bromide. The lines represent average values.

It is possible to improve the precision of measurements by increasing the amount of sample, as far as the heat of solution is independent on concentration. This will be done in experiments with lanthanide halides in future. Also the volume of solvent may be slightly increased. The exothermic effect of crushing the ampoule can be limited by preparing the ampoules with thin walls. In general, we conclude that the presented equipment is respective for solution calorimetry and for the determination of enthalpies of formation for compounds at standard conditions.

Heat of solution of solid $\operatorname{PrBr}_{3}$ and $\mathrm{Rb}_{3} \mathrm{PrBr}_{6}$

This calorimeter is provided for the measurement of the standard enthalpies of formation at $298.15 \mathrm{~K}$ for compounds existing in $\mathrm{MX}_{-} \mathrm{LnX}_{3} \quad(\mathrm{M}=\mathrm{Li} \cdots \mathrm{Cs})$, $(\mathrm{X}=\mathrm{Cl} \cdots \mathrm{I}),(\mathrm{Ln}=\mathrm{La} \cdots \mathrm{Lu})$ systems:

$v 1 \mathrm{AX}+v 2 \mathrm{LnX}_{3}=\mathrm{A}_{v 1} \operatorname{Ln}_{v 2} \mathrm{X}_{(3 v 2+v 1)}$

The enthalpies of formation have been obtained from equation [6]: 


$$
\begin{gathered}
\Delta_{\mathrm{f}} \mathrm{H}\left(\mathrm{M}_{v 1} \operatorname{Ln}_{v 2} \mathrm{X}_{(3 v 2+v 1)}\right)=\Delta_{\text {sol }} \mathrm{H}\left(\mathrm{A}_{v 1} \operatorname{Ln}_{v 2} \mathrm{X}_{(3 v 2+v 1)}\right) \\
-v 1 \Delta_{\text {sol }} \mathrm{H}(\mathrm{MX})-v 2 \Delta_{\text {sol }} \mathrm{H}\left(\operatorname{LnX}_{3}\right),
\end{gathered}
$$

where $\Delta_{\mathrm{f}} \mathrm{H}$ is enthalpy of formation, $\Delta_{\mathrm{sol}} \mathrm{H}$ is enthalpy of solution, and $v 1$ and $v 2$ are the stoichiometry coefficients.

As the solvent $0.01 \mathrm{M} \mathrm{HCl}$ has been used because of the fact that pure lanthanide halides in $\mathrm{H}_{2} \mathrm{O}$ have tendency to hydrolysis with sedimentation which disturb the results. We assumed that differences between enthalpies of solution for compounds in $\mathrm{H}_{2} \mathrm{O}$ and in $0.01 \mathrm{M} \mathrm{HCl}$ are negligibly small. This is shown in results of the enthalpy of solution for $\mathrm{NaCl}$ which was done for both solvents (Table 2).

As an example of the further experiments the enthalpy of formation for $\mathrm{Rb}_{3} \mathrm{PrBr}_{6}$ has been tried to obtain. Preliminary values of the enthalpy of solution in $0.01 \mathrm{M}$ $\mathrm{HCl}$ for $\mathrm{PrBr}_{3}$ obtained in this study is equal to $(-177.2 \pm$ $0.7) \mathrm{kJ} \mathrm{mol}^{-1}$. The enthalpy of solution for $\mathrm{PrBr}_{3}$ excellent agree to the tendency shown in reference data, which are $(-176.3 \pm 0.6)$ and $(-177.8 \pm 2.2)$ in 0.1 and $0.001 \mathrm{M}$ $\mathrm{HCl}$, respectively [7]. The dependence of heat of solution for this compound on concentration is shown in Fig. 4.

The enthalpy of formation for $\mathrm{Rb}_{3} \mathrm{PrBr}_{6}$ has not been determined, because of doubt of existence of this compound at $298.15 \mathrm{~K}$ which appeared during experiment. The obtained enthalpies of solution for $\mathrm{Rb}_{3} \mathrm{PrBr}_{6}$ changes dependently on cooling rate from about -30 to $-200 \mathrm{~kJ} \mathrm{~mol}^{-1}$. The estimated values of enthalpies of solution for frozen phases calculated by the CALPHAD method [8] should be about -195 and $-170 \mathrm{~kJ} \mathrm{~mol}^{-1}$, for high- and low-temperature for $\mathrm{Rb}_{3} \mathrm{PrBr}_{6}$, respectively. This means that in the measured sample high- and low-temperature phases of such compound and other phases can exist in the sample simultaneously. During investigation of dependence of heat capacity on temperature for $\mathrm{Rb}_{3} \operatorname{PrBr}_{6}$, the very small endothermic effect at $394 \mathrm{~K}$ has been observed [9]. The additional DSC experiments have been done with a Setaram DSC 121 differential scanning calorimeter. The temperature range was from 300 to $450 \mathrm{~K}$. For heating rate 1.0 and $0.5 \mathrm{~K} \mathrm{~s}^{-1}$, the very small endothermic effect has been found at temperature $399 \pm 2 \mathrm{~K}$. The value of enthalpy of this effect was $0.098 \pm 0.032 \mathrm{~kJ} \mathrm{~mol}^{-1}$. On the cooling curves the effect was much less evident and was observed at lower temperatures. We conclude that low-temperature phase of $\mathrm{Rb}_{3} \mathrm{PrBr}_{6}$ decomposes to $\mathrm{RbBr}$ and probably $\mathrm{Rb}_{2} \mathrm{PrBr}_{5}$ at temperatures lower than about $399 \mathrm{~K}$. The enthalpy of this process should be higher than obtained because of overcooling the compound and kinetic disturbances of process at low temperature. The enthalpy of solution for the $\mathrm{Rb}_{3} \operatorname{PrBr}_{6}$ at standard conditions has not been obtained, but the results of experiment leads to unexpected conclusion that this compound does not exists at standard temperature.

Acknowledgements Financial support by the Department of Chemistry of Wroclaw University of Technology from budget on science in 2011 under the grant $344120 / \mathrm{Z} 0310$ is gratefully acknowledged.

Open Access This article is distributed under the terms of the Creative Commons Attribution Noncommercial License which permits any noncommercial use, distribution, and reproduction in any medium, provided the original author(s) and source are credited.

\section{References}

1. Calvet E, Prat H. Microcalorimétrie; applications physicochimiques et biologiques. Paris: Masson \& Cie; 1956.

2. Ingier-Stocka E, Rycerz L, M. Berkani, Gaune-Escard M. Thermodynamic and transport properties of the $\mathrm{PrBr} 3-\mathrm{MBr}$ binary systems (M = Li, Na). J Mol Liquids. 2009;148(1):40-4.

3. Archer DG. Thermodynamic properties of synthetic sapphire $(\alpha-\mathrm{Al} 2 \mathrm{O}-3-)$, standard reference material 720 and the effect of temperature-scale differences on thermodynamic properties. J Phys Chem Ref Data. 1993;22(6):1441-53.

4. CRC Handbook of Chemistry and Physics. London: CRC Press, 2002-2003.

5. Wadsö I, Goldberg RN. Standards in isothermal microcalorimetry. Pure Appl Chem. 2001;73(10):1625-39.

6. Mitra S, Uebach J, Seifeert HJJ. Ternary chlorides in the systems $\mathrm{ACl} / \mathrm{TbCl} 3$ (A = K, Rb, Cs). Solid State Chem. 1995;115:484-9.

7. Hurtgen C, Brown D. Thermodynamics of lanthanide elements, part 1. Enthalpies of formation of some lanthanide tribromides. J Chem Soc Dalton Trans. 1980;1:70-5.

8. Kapała J. Modeling of thermodynamic properties of $\mathrm{ABr}-$ PrBr3 (A = Li-Cs) systems. CALPHAD. 2011;35(2):219-23.

9. Rycerz L, Chojnacka I, Berkani M, Gaune-Escard M. Thermodynamic functions of $\mathrm{PrBr}_{3}$ and congruently melting $\mathrm{M}_{3} \mathrm{PrBr}_{6}$ compounds ( $\mathrm{M}=\mathrm{K}, \mathrm{Rb}, \mathrm{Cs})$. J Chem Eng Data. 2011;56:1293-8. 